\title{
Employee Engagement and Its Relationship Towards Normative Commitment in Malaysia Oil and Gas Industry
}

\author{
Ridwan Mokhtar \\ Universiti Teknologi MARA (UiTM), Sabah Branch, \\ Kota Kinabalu, Campus, Malaysia \\ Sylvia Nabila Azwa Ambad \\ Universiti Teknologi MARA (UiTM), Sabah Branch, \\ Kota Kinabalu Campus, Malaysia \\ Sharifah Nurafizah Syed Annuar \\ Universiti Teknologi MARA (UiTM), Sabah Branch, \\ Kota Kinabalu Campus, Malaysia \\ Nelson Lajuni \\ Universiti Malaysia Sabah (UMS), Malaysia
}

Received: Dec. 14, 2020 Accepted: Jan. 20, 2021 Online published: Jan. 28, 2021

doi:10.5296/ijhrs.v11i1.18260

URL: https://doi.org/10.5296/ijhrs.v11i1.18260

\begin{abstract}
The relationship between employee engagement and organisational commitment has been established and documented in past literature. Hitherto, they are still very relevant and remain a pertinent subject to be discussed, especially with the rapid evolution of business and adjustments in the economic setting. However, much of the focus of past studies were surrounding employee engagement divulging organisational commitment. Only a few studies on the impacts of employee engagement on normative commitment have been shown, especially in Malaysia's oil and gas industry. We do not adequately know how employee
\end{abstract}


engagement is associated with normative commitment. Hence, this study goals to examine the effects of employee engagement on normative commitment. Two hundred fifty offshore employees participated in this study. Subsequently, 234 completed responses were collected, and Partial Least Squared-Structural Equation Modelling were used to analyse the data using SmartPLS 3.3.2 version. The findings advise that employee engagement, particularly organisational engagement dimension, has a positive relationship with both normative commitment dimensions among offshore employees in Malaysia. This study provided oil and gas organisation with an improved insight and understanding of the significance of the organisational engagement aspect in improving employees' level of normative commitment among offshore employees. Because of the recent pandemic outbreak, future studies should consider the organisational support rendered by the organisation to offshore employees in predicting the new norms for oil and gas companies. Future studies should also utilise the qualitative approach or employ the Partial Least Square-Multi-Group Analysis (PLS-MGA) to examine whether ethnicity, working tenure, and working locations play an essential role in the relationship between employee engagement and normative commitment.

Keywords: organisational commitment, normative commitment, employee engagement, oil and gas, offshore employee

\section{Introduction}

The new world order was activated because of the unprecedented event post-COVID-19 outbreak, affecting every industry, including the oil and gas (O\&G) industry. The outbreak had caused a restriction movement for most affected nations in an attempt to break the virus chain from spreading further. The outbreak had caused most of the industries player to halt the usual operation of their facilities, reducing the demand for oil and gas further, which interrupted the supply and demand in the world market. For instance, according to Carbon Brief, the percentage of oil refineries operating in the province of Shandong, China, had fallen from $71.4 \%$ in December 2019 to $38.9 \%$ two months later, a reduction of close to half; representing a broader effect on rapid industrial shortage. Particularly, in Malaysia, the impact of the weak oil price has forced the Malaysian government to revisit the 12th Malaysian Plan (12MP) while considering the implications of COVID-19, which has caused an economic slowdown in the country as well as globally. Therefore, with no sign of available vaccine to win the battle soon, O\&G companies need to be prepared with prolonging events due to the increased challenges for companies' survival, especially in retaining good talents and sustaining their commitment towards the company's corporate strategy. Thus, to ensure good talents remain with O\&G companies, it is vital to understand how employee engagement translated into organisational commitment.

Employee engagement is highly related to the success of any organisation because disengagement, or alienation, will lead to employees' lack of motivation and commitment (May, Gilson \& Harter, 2004). In fact, employee engagement has continuously been linked to positive job-related outcomes, such as retention of talented workers (Harter, Hayes \& Schmidt, 2002), affective, attitudinal, or organisational commitment (Saks, 2006). Based on a recent study by Qualtrics, Malaysians are more engaged as compared to their global peers, 
with the average employee engagement score across Malaysia at about 54\%, slightly above the global average of 53\%. In the past few decades, an abundance of research focused on the relationship between employee engagement and organisational commitment. Work engagement ultimately leads to organisational commitment, and it could empower employees to make their own decisions about work, control their work, and achieve their goals. It may even help them become more engaged in their jobs, and with proper rewards and feedback, it could enhance employee commitment (Hakanen, Schaufeli, \& Ahola, 2008; Wachira, 2013). In line with the social exchange theory, employees highly engaged in their job and organisation tend to exhibit more affection towards their organisation, as indicated by higher levels of affective commitment and feeling more obliged to stay longer, proven by the high normative commitment and less continuance commitment (Albdour \& Altarawneh, 2014). Organisational commitment refers to how much an employee identifies with the organisation and wants to continue actively participating in it, keen to make an effort on its behalf (Newstrom, 2015). Also, organisational commitment reflects the attitudinal experience of commitment occurs apart from, or as a consequence of, day-to-day work activity (Beardwell \& Thompson, 2014). To date, most of the studies were conducted on affective commitment dimension. Moreover, limited number of studies have been performed in the O\&G industry, especially in Malaysia, especially on normative commitment. This study could provide clear organisational insight and perspective to various stakeholders, especially the O\&G industry, offshore operators, and the government. Therefore, this research aims to examine the relationship between employee engagement (job engagement and organisational engagement) and normative commitment dimensions, namely indebted obligation and moral imperative.

\section{Literature Review}

\subsection{Normative Commitment}

According to Allen and Meyer (1990), there are three key types of organisational commitment, namely normative commitment (whereby employees feel obligated to stay with the organisation, which is the focus of this study), continuance commitment (employees feel they need to stay with the organisation given the cost of leaving the organisation), and affective commitment (employees emotionally attached to the organisation). Normative commitment explains that employees with strong normative commitment will remain with an organisation because they feel guilty about leaving and will stay because they believe it is the "right and moral" thing to do (Allen \& Meyer, 1990). Thus, employees remain with the organisation because they feel they should. According to Wiener and Gechman (1977), employees' early socialization apart from their family and as a newcomer to an organisation formed their normative commitment toward the organisation. Besides, normative commitment development might arise from the "psychological contract" between an employee and the organisation (Roussenau, 1995). Another possible explanation is that normative commitment might be the outcome of feeling indebted to an organisation due to the advance rewards awarded by the organisation to employees (Scholl, 1981). A study conducted in the public sector found a negative relationship between normative commitment and role conflict and ambiguity. Employees with a high level of role conflict and ambiguity were less likely to have an emotional attachment to the organisation or feeling obligated to 
stay in the public sector, and less likely to identify with the organisation's goals and values (Addae, Parboteeah, \& Velinor, 2008). Meanwhile, San Martin (2008) revealed that solidarity and satisfaction are somewhat affecting employees' normative commitment. The sense of satisfaction in carrying their duties and responsibilities indicated a significant negative influence on normative commitment. A possible explanation for this could be found in the situation where employees satisfied in their job, feel emotionally connected to the organisation and less obligated to work; they are more relaxed and think that less effort is needed to maintain a good working relationship (San Martin, 2008). Based on social exchange theory by Blau (1964), employees highly engaged in their job and organisation tend to exhibit more affection towards their organisation through higher levels of affective commitment. They will want to remain with the organisation due to the sense of obligation; hence, their high normative commitment and less continuance commitment (Albdour \& Altarawneh, 2014).

Earlier studies introduced the possibility of normative commitment (employees' sense of obligation to the organisation) having "dual nature" of its important characteristics, which employees could experience depending on the relative levels of affective commitment and continuance commitment. Firstly, the normative commitment that is combined with high affective commitment and low continuance commitment would lead to organisational outcomes that are of high value. Such a profile is associated with employees' beliefs (such as the organisation's inherent goodness), leading to the term "moral imperative" that describes normative commitment. Secondly, the normative commitment combined with low affective commitment and high continuance commitment would lead to a lower level of organisational outcomes. This was when employees experienced the sense of an "indebted obligation." It involves a course of action that would benefit the organisation, but the motivation behind the actions is mostly "to avoid the social costs of failing to do so" (Gellatly, Meyer, \& Luchak, 2006; Meyer \& Parfyonova, 2010). Thus, the conclusion is that the dual nature of normative commitment is determined by the context in which it is experienced, as described in the two cases mentioned above: a) high affective commitment with low continuance commitment, and b) low affective commitment with high continuance commitment. Nevertheless, the dual nature of normative commitment was inferred based on the observation of the differences in the relationship between commitment profiles and outcome variables (employees' behaviour), and the posited sense of obligation. Accordingly, to shed light on this matter requires further study to determine the dual nature of normative commitment role in causing employees to have such a "mindset" - an indebted obligation or moral imperative, which, in turn, affected employees' work-related behaviour. Moreover, normative commitment does not operate independently; the affective commitment and continuance commitment both play a role in forming a distinct commitment profile. How employees' distinct patterns of commitment profiles might influence their mindsets is unknown. Therefore, the mindset concept pertaining to employees' organisational commitment is now given due attention.

\subsection{Employee Engagement}

In organisation sciences, employee engagement is now recognised as a critical research topic. (Sonnentag, 2011). Employee Engagement was defined as the "harnessing of organisation 
members' selves to their work roles: in engagement, people employ and express themselves physically, cognitively, emotionally, and mentally during role performances" (Khan, 1990, p. 694). Cognitively, it refers to employees' beliefs about the organisation and working conditions, as well as the leaders. Emotionally, it concerns how employees' feelings towards the three elements, whether the employees' attitude towards the organisation and the leaders are positive or negative. Physically, the concerns are about the individuals' physical energies exerted to achieve their roles' demands. Kahn (1990) suggested three antecedents to attain an engaged state: psychological meaningfulness, psychological safety, and psychological availability. Meanwhile, Rothbard (2011) defined employee engagement as employees being psychologically present during work roles; the psychological presence comprises two vital components, namely absorption and attention. Employee engagement is a fulfilling and positive psychological state of mind manifested by absorption, dedication, and vigour (Schaufeli, Salanova, González-Roma, \& Bakker, 2002). A recent study concluded that employee engagement is more apparent in professional and skilled workers than other groups of workers (Khodakarami \& Dirani, 2020). Employee engagement is defined as the extent to which individuals are attentive and absorbed in their roles. As a multi-dimensional construct, employee engagement is conceptualised as consisting of two types: job engagement and organisational engagement. Meanwhile, job engagement is the extent to which individuals are fascinated with the performance of their job role (Saks, 2006). Thus, it is predicted that job engagement will be related to normative commitment (indebted obligation and moral imperative), as follows:

H1: Job engagement positively influences indebted obligation

$\mathrm{H} 2$ : Job engagement positively influences moral imperative

Meanwhile, the extent to which an individual is psychologically present as a member of an organisation is known as organisational engagement (Saks, 2006). Therefore, it is predicted that organisational engagement will be related to normative commitment (indebted obligation and moral imperative); thus, the following hypotheses are formulated:

H3: Organisational engagement positively influences indebted obligation

H4: Organisational engagement positively influences moral imperative

\section{Data and Methodology}

A quantitative approach was employed to conduct this study. The respondents consisted of Malaysians working in different offshore locations in Malaysia, namely Sabah, Sarawak, and Peninsular Malaysia. In order to ensure that data are collected from sound sources, this study employed the non-probability purposive sampling technique. A 5-point Likert scale anchored by "strongly disagree" (1) to "strongly agree" (5) was applied to measure the independent and dependent variables. Sample size estimation was determined using G*power 3.0 analysis (Faul, Erdfelder, Lang, \& Buchner, 2007). Using the G-Power Analysis software, the effect size of $\mathrm{f} 2 \mathrm{0.15}, \alpha$ error pro 0.05 , and power Gf 0.95 with 1 tested predictor. Therefore, the minimum sample for this study was 89 respondents. Two hundred fifty respondents participated, but only 234 completed questionnaires were deemed usable. Figure 1 exhibits the conceptual framework that contained statements of two variables under investigation. The 
variables were examined using multiple items (Hayduk \& Littvay, 2012), and the data was then analysed using SmartPLS 3.0 (Ringle, Wende, \& Becker, 2015) to assess the hypotheses.

\subsection{Conceptual Framework}

Past literature mentioned that employee engagement is capable of influencing the normative commitment. Therefore, based on the previous literature, this study would further explore the relationship of each dimension of employee engagement by examining how job engagement and organisational engagement support normative commitment, which comprises indebted obligation and moral imperative, as shown in Figure 1.

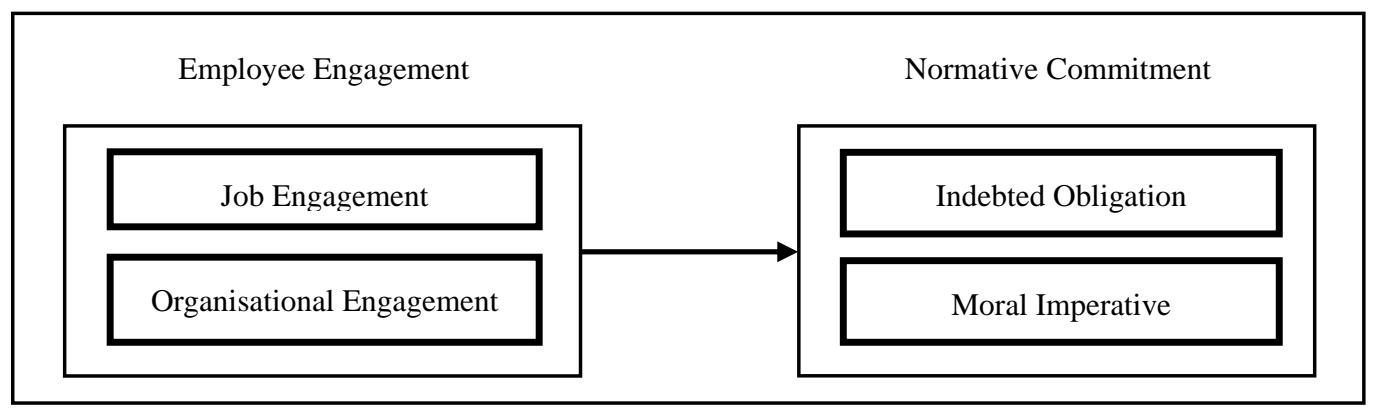

Figure 1. Conceptual Framework

\subsection{Estimation Procedure}

As shown in Table 1, the survey questionnaire is divided into three parts. Part 1 contains the respondents' demographic information. Part 2 measures the level of employee engagement at work using 11 items adapted from Saks (2006). The final part of the questionnaire measures the normative commitment, which contains seven items adapted from Jaros (2015), further divided into two subscales, namely indebted obligation and moral imperative.

Table 1. Sample Measurement of Items and Sources

\begin{tabular}{|c|c|c|c|}
\hline Construct & Dimension & Sample Items & Source \\
\hline \multirow{3}{*}{$\begin{array}{c}\text { Employee } \\
\text { Engagement }\end{array}$} & Job & 1. I really throw myself into my job & \multirow{3}{*}{$\begin{array}{l}\text { Saks } \\
(2006)\end{array}$} \\
\hline & engagement & 2. Sometimes I am so into my job that I lose track of time & \\
\hline & $\begin{array}{l}\text { Organisation } \\
\text { engagement }\end{array}$ & $\begin{array}{l}\text { 1. Being a member of this organisation is very captivating } \\
\text { 2. One of the most exciting things for me is getting } \\
\text { involved with things happening in this organisation }\end{array}$ & \\
\hline \multirow{2}{*}{$\begin{array}{c}\text { Normative } \\
\text { Commitment }\end{array}$} & $\begin{array}{l}\text { Indebted } \\
\text { Obligation }\end{array}$ & $\begin{array}{l}\text { 1. I feel that I owe this organisation quite a bit because of } \\
\text { what it has done for me } \\
\text { 2. My organisation deserves my loyalty because of its } \\
\text { treatment towards me }\end{array}$ & \multirow{2}{*}{$\begin{array}{l}\text { Jaros } \\
(2015)\end{array}$} \\
\hline & $\begin{array}{c}\text { Moral } \\
\text { Imperative }\end{array}$ & $\begin{array}{l}\text { 1. I am loyal to this organisation because my values are } \\
\text { largely its values } \\
\text { 2. This organisation has a mission that I believe in }\end{array}$ & \\
\hline
\end{tabular}




\section{$\Lambda$ Macrothink}

\section{Results and Findings}

As shown in Table 2, out of 234 respondents of the study, more than $90.2 \%$ of them were males, and the remaining $9.8 \%$ were females. Married employees made up $78.5 \%$ of the total number of respondents, compared to $20.5 \%$ of single employees. About $41.9 \%$ were diploma holders, followed by degree holders $(29.9 \%)$. The remaining respondents possessed other qualifications (25.6\%), and only about $2.6 \%$ have master's degrees. Meanwhile, the majority of the participating respondents were Malay (38.9\%), followed by Sabahans (30.3\%), Sarawakians (16.2\%), other ethnicities $(7.3 \%)$, Chinese $(6.4 \%)$, and only a few Indians $(0.9 \%)$. The work locations were equally distributed in Peninsular Malaysia, Sabah, and Sarawak. In terms of working experience, the majority of the respondents have more than five years of working experience $(66.2 \%)$, followed by those who have two to five years of working experience, and the remaining have served less than two years (12.8\%). Therefore, it can be concluded that the majority of the respondents in this study were mainly dominated by males, married, highly skilled, and educated. The profile of respondents of this study is summarised in Table 2.

Table 2. Demographic Information on Respondents

\begin{tabular}{|c|c|c|c|}
\hline Variable & & Frequency & $(\%)$ \\
\hline \multirow{2}{*}{ Gender } & Male & 211 & 90.2 \\
\hline & Female & 23 & 9.8 \\
\hline \multirow{4}{*}{$\begin{array}{l}\text { Marital } \\
\text { Status }\end{array}$} & Single & 48 & 20.5 \\
\hline & Married & 184 & 78.6 \\
\hline & Widow & 1 & 0.4 \\
\hline & Widower & 1 & 0.4 \\
\hline \multirow{5}{*}{ Education } & Doctorate & 0 & 0.0 \\
\hline & Master & 6 & 2.6 \\
\hline & Degree & 70 & 29.9 \\
\hline & Diploma & 98 & 41.9 \\
\hline & Others & 60 & 25.6 \\
\hline \multirow{6}{*}{ Race } & Malay & 91 & 38.9 \\
\hline & Chinese & 15 & 6.4 \\
\hline & Indian & 2 & 0.9 \\
\hline & Sabah Natives & 71 & 30.3 \\
\hline & Sarawak Natives & 38 & 16.2 \\
\hline & Others & 17 & 7.3 \\
\hline \multirow{3}{*}{$\begin{array}{c}\text { Work } \\
\text { Location }\end{array}$} & Sabah & 78 & 33.3 \\
\hline & Sarawak & 78 & 33.3 \\
\hline & Peninsular Malaysia & 78 & 33.3 \\
\hline \multirow{3}{*}{$\begin{array}{l}\text { Working } \\
\text { Tenure }\end{array}$} & Less than 2 years & 30 & 12.8 \\
\hline & From $2-5$ years & 49 & 20.9 \\
\hline & More than 5 years & 155 & 66.2 \\
\hline
\end{tabular}

\subsection{Data Analysis}

Utilising Partial Least Square-Structural Equation Modelling (PLS-SEM) approach through SmartPLS software version 3.0 (Ringle et al., 2015), data analysis was performed in two stages. The measurement model was assessed to determine the reliability and validity of the constructs during the first stage. While stage two entails the evaluations of the structural model for hypotheses testing. However, the second stage assessment can only be conducted if 
the first stage passed the reliability and validity tests.

\subsection{The Measurement Model}

Table 3 reveals the results of constructs' composite reliability (CR) and convergent validity testing. The results confirm that the constructs have high internal consistency (Roldán \& Sánchez-Franco, 2012) and sufficient average variance extracted (AVE) to validate the convergent validity (Hair, Hult, Ringle, Sarstedt, \& Thiele, 2017). One indicator deleted as the Cronbach's alpha and composite reliability were below 0.708 (Hair et al., 2017). Most indicators which measuring each construct achieved satisfactory loadings value that higher than the threshold value of 0.708 , as supported by Hair et al. (2017). Two indicators were below 0.708; however, these indicators were not deleted if the AVE is equal or above 0.500, and the respective indicators were above 0.400 (Hair et al., 2017). The composite reliability (CR) value of job engagement was 0.891, organisational engagement, 0.942, indebted obligation, 0.913, and moral imperative, 0.945, respectively, implying that these constructs possess high internal consistency. Moreover, these constructs also show satisfactory convergent validity with the average variance extracted (AVE) value for the respective construct higher than the threshold value of 0.500 , in which demonstrating that the indicators describe more than $50 \%$ of the constructs' variances.

Table 3. Reflective Measurement Model

\begin{tabular}{|c|c|c|c|c|c|}
\hline Construct & Dimension & Item & Loadings & CR & AVE \\
\hline \multirow{11}{*}{$\begin{array}{c}\text { Employee } \\
\text { Engagement }\end{array}$} & \multirow{6}{*}{$\begin{array}{l}\text { Job Engagement } \\
\text { (JE) }\end{array}$} & EEJE1 & 0.786 & 0.891 & 0.580 \\
\hline & & EEJE2 & 0.632 & & \\
\hline & & EEJE3 & 0.826 & & \\
\hline & & EEJE4 & 0.822 & & \\
\hline & & EEJE5 & 0.625 & & \\
\hline & & EEJE6 & 0.845 & & \\
\hline & \multirow{5}{*}{$\begin{array}{l}\text { Organisational Engagement } \\
\qquad(\mathrm{OE})\end{array}$} & EEOE1 & 0.907 & 0.942 & 0.765 \\
\hline & & EEOE2 & 0.887 & & \\
\hline & & EEOE4 & 0.842 & & \\
\hline & & EEOE5 & 0.871 & & \\
\hline & & EEOE6 & 0.865 & & \\
\hline \multirow{7}{*}{$\begin{array}{c}\text { Normative } \\
\text { Commitment }\end{array}$} & \multirow{3}{*}{$\begin{array}{l}\text { Indebted Obligation } \\
\text { (IO) }\end{array}$} & NCIO1 & 0.863 & 0.913 & 0.778 \\
\hline & & $\mathrm{NCIO} 2$ & 0.903 & & \\
\hline & & $\mathrm{NCIO} 3$ & 0.880 & & \\
\hline & \multirow{4}{*}{$\begin{array}{l}\text { Moral Imperative } \\
\text { (MI) }\end{array}$} & NCMI1 & 0.839 & 0.945 & 0.811 \\
\hline & & NCMI2 & 0.913 & & \\
\hline & & NCMI3 & 0.921 & & \\
\hline & & NCMI4 & 0.927 & & \\
\hline
\end{tabular}

Note: EEOE3 item was deleted due to poor loading $<.708$

(Hair, Black, Babin, \& Anderson., 2010, \& Hair, Hult, Ringle, \& Sarstedt, 2014)

Table 4 presents the HTMT criterion to evaluate discriminant validity, whereby the square root of the AVE values for each latent variable was found to be higher than the correlation values between all variables (Ringle et al., 2015). The result specifies that discriminant validity is well-established at $\mathrm{HTMT}_{.85}$ (Kline, 2011). This study applies heterotrait-monotrait ratio of correlations criterion by Henseler, Ringle, and Sarstedt (2015) to assess the 
discriminant validity. The result suggests that the constructs' correlation values did not violate the stringent criterion $\left(\mathrm{HTMT}_{.85}\right.$ ), which implies that the discriminant validity issue is of no concern. Thus, with no multicollinearity issue between items loaded on different constructs in the outer model, the structural model assessment can proceed to test the study's hypotheses.

Table 4. Discriminant Validity

\begin{tabular}{c|cccc}
\hline \multicolumn{1}{c}{} & IO & JE & MI & OE \\
\hline IO & - & & & \\
JE & 0.561 & - & & \\
MI & 0.836 & 0.685 & - & \\
OE & 0.805 & 0.768 & 0.805 & - \\
\hline
\end{tabular}

Note: Discriminant validity is well-established at $\mathrm{HTMT}_{.85}$ (Kline, 2011)

\subsection{The Structural Model}

This section discusses the testing of the structural model to determine the proposed relationship between variables in the research framework. Prior to measuring the structural model, this study addresses the issue of multicollinearity using the collinearity test. The variance inflator factor (VIF) values below 3.3 (Diamantopoulous \& Siguaw, 2006) for each of the constructs suggest that the issue of multicollinearity is not a concern. Next, a 5000-bootstrap resampling of data is conducted to examine the hypotheses of this study (Hair et al., 2017). Table 5 demonstrates the assessment of the path coefficient, which is represented by Beta values for each path relationship.

The results show that three out of four hypotheses were indeed supported. The results for direct effects indicate that job engagement and organisational engagement have a positive influence on moral imperative and indebted obligation. Specifically, the study found support for H2 (JE $\rightarrow \mathrm{MI}, \beta=0.149, p<0.010, \mathrm{LLCI}=0.057$, ULCI $=0.266), \mathrm{H} 3(\mathrm{OE} \rightarrow \mathrm{IO}, \beta=$ $0.669, p<0.000$, LLCI $=0.545$, ULCI $=0.790)$, and H4 (OE $\rightarrow \mathrm{MI}, \beta=0.721, p<0.000$, LLCI $=0.608$, ULCI $=0.815$ ). Thus, $\mathrm{H} 2, \mathrm{H} 3$, and $\mathrm{H} 4$ are supported, whereas $\mathrm{H} 1$ is not supported.

Table 5. Hypothesis Testing for Direct Effect

\begin{tabular}{c|ccccccc}
\hline \multicolumn{1}{l}{ HYPOTHESES } & BETA & $\begin{array}{c}\text { STD. } \\
\text { ERROR }\end{array}$ & T-VALUES & P-VALUES & LLCI & ULCI & DECISION \\
\hline H1: JE $\rightarrow$ IO & 0.063 & 0.076 & 0.821 & 0.206 & -0.068 & 0.182 & Not Supported \\
H2: JE $\rightarrow$ MI & 0.149 & 0.064 & 2.335 & 0.010 & 0.057 & 0.266 & Supported \\
H3: OE $\rightarrow$ IO & 0.669 & 0.076 & 8.776 & 0.000 & 0.545 & 0.790 & Supported \\
H4: OE $\rightarrow$ MI & 0.721 & 0.064 & 11.332 & 0.000 & 0.608 & 0.815 & Supported \\
\hline
\end{tabular}

Note: p-value<0.01, t-value>2.33 (one-tailed) as per Hair et al. (2017)

Table 6 and Figure 2 summarise the assessment of the path coefficient, which suggests the relationship between employee engagement and normative commitment. The result proves 
that employee engagement is indeed influencing normative commitment. Specifically, the study found support for $\mathrm{EE} \rightarrow \mathrm{NC}(\beta=0.807, p<0.000, \mathrm{LLCI}=0.753, \mathrm{ULCI}=0.846)$.

Table 6. Specific Direct Effect between EE and NC

\begin{tabular}{cccccccc}
\hline $\begin{array}{c}\text { PATH } \\
\text { COEFFICIENT }\end{array}$ & BETA & $\begin{array}{c}\text { STD. } \\
\text { ERROR }\end{array}$ & T-VALUES & P-VALUES & LLCI & ULCI & DECISION \\
\hline $\mathbf{E E} \rightarrow \mathbf{N C}$ & 0.807 & 0.028 & 29.319 & 0.000 & 0.753 & 0.846 & Supported \\
\hline
\end{tabular}

Note: $\mathrm{p}$-value $<0.01$, t-value $>2.33$ (one-tailed) as per Hair et al. (2017)

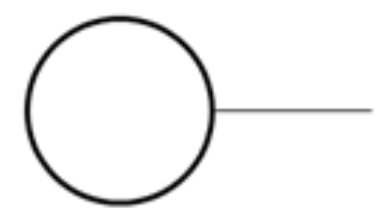

EE

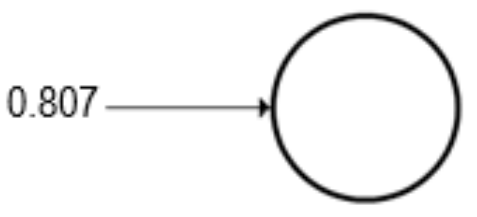

$\mathrm{NC}$

Figure 2. Specific Path Coefficient of EE and NC

\subsection{Model Quality Assessment}

Table 5 displays the quality of the model. We assessed the effect size $\left(\mathrm{f}^{2}\right)$, the coefficient of determination $\left(\mathrm{R}^{2}\right)$, multicollinearity issues (VIF values), and the predictive relevance $\left(\mathrm{Q}^{2}\right)$ of exogenous variables on the endogenous variable in this study. From this bootstrapping process, $t$-test results were generated to determine the significance of the path model relationships. According to Cohen (1988), $\mathrm{R}^{2}$ values for endogenous latent variables are assessed based on the following criteria: 0.26 is substantial, 0.13 is moderate, and 0.02 is weak. Lohmöller (1989) postulates that the path coefficients range that is greater than 0.1 is acceptable. In addition, evaluation of the magnitude of the $\mathrm{R}^{2}$ values as one of the criterion of predictive accuracy, $\mathrm{Q}^{2}$ value can also be observed as $\mathrm{Q}^{2}$ value provide model's predictive relevance. When a PLS-SEM model exhibits predictive relevance, it will predict accurately the data points of the indicators in measurement models of multi-item, as well as single-item endogenous constructs. For SEM models, $\mathrm{Q}^{2}$ values larger than zero for a specific endogenous latent variable indicate the path model's predictive relevance for a particular construct. Conversely, a $\mathrm{Q}^{2}$ value of zero or below indicates a lack of predictive relevance (Hair et al., 2014).

To be specific, organisational engagement (H3 and H4) is shown to carry substantial effect size $\mathrm{f}^{2}$ on indebted obligation and moral imperative. Job engagement ( $\mathrm{H} 1$ and $\mathrm{H} 2$ ), on the other hand, indicates a small effect size $\mathrm{f}^{2}$ on indebted obligation and moral imperative (Cohen, 1988). The coefficient of determination represented by $\mathrm{R}^{2}$, which explains whether job engagement and organisational engagement could explain indebted obligation and moral imperative, indicates substantial effect (Chin, 1998). Besides, multicollinearity between indicators was assessed. All indicators for the variables satisfied the VIF values, and consistently below the threshold value of 5.0 (Hair et al., 2014) and 3.3 (Diamantopoulos \& Siguaw, 2006). Therefore, it can be concluded that collinearity issues do not reach critical 


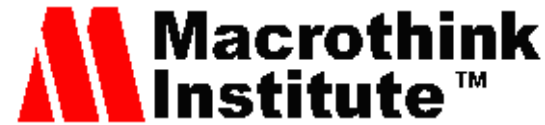

International Journal of Human Resource Studies

ISSN 2162-3058

2021, Vol. 11, No. 1

levels in all variables and are not an issue for the estimation of the PLS path model. Specifically, the $\mathrm{R}^{2}$ value for indebted obligation and moral imperative are 0.507 and 0.684 , respectively, suggesting that job engagement and organisational engagement are able to explain the indebted obligation and moral imperative. The $f^{2}$ values show that organisational engagement have substantial effect size on both indebted obligation $\left(f^{2}=0.518\right)$ and moral imperative $\left(f^{2}=0.941\right)$, whereas job engagement has a weak effect size on both indebted obligation $\left(f^{2}=0.005\right)$ and moral imperative $\left(f^{2}=0.041\right)$. The predictive relevance values of all exogenous variables towards endogenous variables were larger than 0 , indicating that the independent variables (job engagement and organisational engagement) could predict the indebted obligation and moral imperative, as presented by $\mathrm{Q}^{2}$ using the blindfolding procedure (Hair et al., 2017).

Table 6. Model Quality Assessment

\begin{tabular}{c|ccccc}
\hline HYPOTHESIS & DIRECT EFFECT & $\mathbf{F}^{\mathbf{2}}$ & $\mathbf{R}^{\mathbf{2}}$ & VIF & $\mathbf{Q}^{\mathbf{2}}$ \\
\hline $\mathbf{H 1}$ & $\mathrm{JE} \rightarrow \mathrm{IO}$ & 0.005 & 0.507 & 1.746 & 0.380 \\
$\mathbf{H 2}$ & $\mathrm{JE} \rightarrow \mathrm{MI}$ & 0.041 & 0.684 & 1.746 & 0.549 \\
$\mathbf{H 3}$ & $\mathrm{OE} \rightarrow \mathrm{IO}$ & 0.518 & & 1.746 & \\
$\mathbf{H 4}$ & $\mathrm{OE} \rightarrow \mathrm{MI}$ & 0.941 & & 1.746 & \\
\hline
\end{tabular}

Lateral Collinearity: VIF $\leq 3.3$ (Diamantopoulos \& Siguaw, 2006)

$\mathrm{R}^{2} \geq 0.26$ consider Substantial (Cohen, 1988)

$\mathrm{F}^{2} \geq 0.35$ consider Substantial (Cohen, 1988)

$\mathrm{Q}^{2}>0.00$ consider large (Hair et al., 2017)

\section{Discussion and Recommendation}

This study intention is to examine the relationship of employee engagement towards normative commitment, which involved 234 offshore employees. The findings show that employee engagement has a positive correlation with normative commitment among offshore employees in Malaysia. Due to the nature of job engagement that is more towards the drive-by of respective employees towards their level of attitude, enthusiasm, or passion in performing the assigned task, as well as the cooperation level while performing the job within the team or peer will not give any major bearing in term of creating indebted obligation towards the O\&G companies. The outcomes of respective employees are subject to each employee themselves as their experience while working offshore differs from one another. The study also suggests that organisational engagement plays a major role in normative commitment for both dimensions. Therefore, to enhance offshore employees' level on normative commitment, the $\mathrm{O} \& \mathrm{G}$ companies need to emphasise more on its effort to connect employees' values with the organisation's core values and culture by developing strong drive of affective commitment or a sense of purpose towards the organisation among employees (Meyer \& Parfyonova, 2010). This can be inculcated through continuous engagement and transparency in information provided that bind employees' self-values, especially by higher management, in line with organisational support theory that top management will have a 
higher impact on employees compared to lower management (Eisenberger, Huntington, Hutchison, \& Sowa, 1986). In summary, the study reveals that employees working at the offshore environment setting in Malaysia O\&G companies had a significant relationship towards moral imperative concerning normative commitment, which is supported by previous literature that suggests a substantially greater benefit for both employers and employees when normative commitment is experienced as a moral duty instead of indebtedness (Kanter, 1968; Etzioni, 1975; Wiener, 1982; Meyer \& Parfyonova, 2010).

\section{Limitation of Study and Future Direction}

This study is not spare without any limitations as the data were gathered from employees working at oil and gas offshore facilities in Malaysia. Therefore, it cannot be generalised to other countries or industries in Malaysia. Perspective wise, since the study is conducted among offshore employees, the working environment may be dissimilar compared to those working at onshore setting. Hence, we propose that upcoming studies should evaluate the impacts of employee engagement and normative commitment on other upstream and downstream industries to further generalise the findings. Future studies should also utilise qualitative approach or adopt Partial Least Square-Multigroup Analysis (PLS-MGA) to examine whether ethnicity, working tenure, and working locations play an important role in the relationship between employee engagement and normative commitment.

\section{References}

Addae, H. M., Parboteeah, K. P., \& Velinor, N. (2008). Role stressors and organisational commitment: Public sector employment in St Lucia. International Journal of Manpower, 29(6), 567-582. https://doi.org/10.1108/01437720810904220

Albdour, A. A., \& Altarawneh, I. I. (2014). Employee engagement and organizational commitment: Evidence from Jordan. International Journal of Business, 19(2), 192-212. Retrieved from https://www.researchgate.net/publication/314759577

Allen, N. J., \& Meyer, J. P. (1990). The measurement and antecedents of affective, continuance and normative commitment to the organisation. Journal of Occupational Psychology, 63(1), 1-18. https://doi.org/10.1111/j.2044-8325.1990.tb00506.x

Beardwell, J., \& Thompson, A. (2014). Human resource management: A contemporary approach (7th ed.). Harlow: Pearson Education Limited.

Blau, P. M. (1964). Exchange and power in social life. New York, NY: John Wiley.

Chin, W. W. (1998). Issues and opinion on structural equation modeling. MIS Quarterly, 22(1), 7-16. Retrieved from https://www.researchgate.net/publication/220260360

Cohen, J. (1988). Statistical power analysis for the behavioral sciences (2nd ed.). Hillsdale, NJ: Lawrence Earlbaum Associates.

Diamantopoulos, A., \& Siguaw, J. A. (2006). Formative versus reflective indicators in organisational measure development: A comparison and empirical illustration. British Journal of Management, 17(4), 263-282. https://doi.org/10.1111/j.1467-8551.2006.00500.x 
Eisenberger, R., Huntington, R., Hutchison, S., \& Sowa, D. (1986). Perceived organizational support. Journal of Applied Psychology, 71(3) 500-507. https://doi.org/10.1037/0021-9010.71.3.500

Etzioni, A. (1975). A comparative analysis of complex organisations. New York: Free Press.

Faul, F., Erdfelder, E., Lang, A. G., \& Buchner, A. (2007). G*Power 3: A flexible statistical power analysis program for the social, behavioral and biomedical sciences. Behavior Research Methods, 39, 175-191. https://doi.org/10.3758/BF03193146

Gellatly, I. R., Meyer, J. P., \& Luchak, A. A. (2006). Combined effects of the three commitment components on focal and discretionary behaviours: A test of Meyer and Herscovitch's propositions. Journal of Vocational Behavior, 69(2), 331-345. https://doi.org/10.1016/j.jvb.2005.12.005

Hair, J. F., Jr. Black, W. C., Babin, B. J., \& Anderson, R. E. (2010). Multivariate data analysis (7th ed.). Upper Saddle River, NJ: Pearson.

Hair, J. F., Jr., Hult, G. T. M., Ringle, C. M., \& Sarstedt, M. (2014). A primer on partial least squares structural equation modeling (PLS-SEM). Thousand Oaks, California: SAGE.

Hair, J. F., Hult, G. T. M., Ringle, C. M., Sarstedt, M., \& Thiele, K. O. (2017). Mirror, mirror on the wall: A comparative evaluation of composite-based structural equation modelling methods. Journal of the Academy of Marketing Science, 45, 616-632. https://doi.org/10.1007/s11747-017-0517-x

Hakanen, J. J., Schaufeli, W. B., \& Ahola, K. (2008). The job demands-resources model: A three-year cross-lagged study of burnout, depression, commitment, and work engagement. Work and Stress, 22(3), 224-241. https://doi.org/10.1080/02678370802379432

Harter, J. K., Schmidt, F. L., \& Hayes, T. L. (2002). Business-unit-level relationship between employee satisfaction, employee engagement, and business outcomes: A meta-analysis. Journal of Applied Psychology, 87(2), 268-279. https://doi.org/10.1037/0021-9010.87.2.268

Hayduk, L. A., \& Littvay, L. (2012). Should researchers use single indicators, best indicators, or multiple indicators in structural equation models? BMC Medical Research Methodology, 12, 159. https://doi.org/10.1186/1471-2288-12-159

Henseler, J., Ringle, C. M., \& Sarstedt, M. (2015). A new criterion for assessing discriminant validity in variance-based structural equation modeling. Journal of the Academy of Marketing Science, 43, 115-135. https://doi.org/10.1007/s11747-014-0403-8

Jaros, S. (2015). Meyer and Allen model of organisational commitment: Measurement issues. Icfai Journal of Organizational Behavior, 6(4), 7-25. Retrieved from https://www.academia.edu/35387821

Kahn, W. A. (1990). Psychological conditions of personal engagement and disengagement at work. Academy of Management Journal, 33(4), 692-724. https://doi.org/10.5465/256287

Kanter, R. M. (1968). Commitment and social organisation: A study of commitment 
mechanisms in utopian communities. American Sociological Review, 33(4), 499-517. https://doi.org/10.2307/2092438

Khodakarami, N., \& Dirani, K. (2020). Drivers of employee engagement: differences by work area and gender. Industrial and Commercial Training, 52(1), 81-91. https://doi.org/10.1108/ICT-06-2019-0060

Kline, R. B. (2011). Principles and practice of structural equation modelling (3rd ed.). New York: Guilford Press.

Lohmöller, J.-B. (1989). Latent variable path modeling with partial least squares. Verlag: Physica-Verlag. https://doi.org/10.1007/978-3-642-52512-4

May, D. R., Gilson, R. L., \& Harter L. M. (2004). The psychological conditions of meaningfulness, safety and availability and the engagement of the human spirit at work. Journal of Occupational and Organizational Psychology, 77, 11-37. https://doi.org/10.1348/096317904322915892

Meyer, J. P., \& Parfyonova, N. M. (2010). Normative commitment in the workplace: A theoretical analysis and re-conceptualization. Human Resource Management Review, 20(4), 283-294. https://doi.org/10.1016/j.hrmr.2009.09.001

Newstrom, J. W. (2015). Organisation behavior: Human behavior at work (14th ed.). New York, NY: McGraw-Hill Education.

Ringle, C., Wende, S., \& Becker, J.-M. (2015). SmartPLS 3. Boenningstedt: SmartPLS $\mathrm{GmbH}$.

Roldán, J. L., \& Sánchez-Franco, M. J. (2012). Variance-based structural equation modeling: Guidelines for using partial least squares. In M. Mora, O. Gelman, A. L. Steenkamp, \& M. Raisinghani (Eds.), Research methodologies, innovations and philosophies in software systems engineering and information systems (pp. 193-221). Hershey, PA: IGI Global. https://doi.org/10.4018/978-1-4666-0179-6.ch010

Roussenau, D. M. (1995). Promises in action: Psychological contracts in organisations. Newbury Park, CA: Sage.

Rothbard, N. (2001). Enriching or depleting? The dynamics of engagement in work and family roles. Administrative Science Quarterly, 46(4), 655-684. https://doi.org/10.2307/3094827

Saks, A. M. (2006). Antecedents and consequences of employee engagement. Journal of Managerial Psychology, 21(7), 600-619. https://doi.org/10.1108/02683940610690169

San Martín, S. (2008). Relational and economic antecedents of organisational commitment. Personnel Review, 37(6), 589-608. https://doi.org/10.1108/00483480810906856

Schaufeli, W. B., Salanova, M., González-Roma, V. A., \& Bakker, A. B. (2002). The measurement of engagement and burnout: A two sample confirmatory factor analytic approach. Journal of Happiness Studies, 3, 71-92. https://doi.org/10.1023/A:1015630930326 


\section{Macrothink}

International Journal of Human Resource Studies

ISSN 2162-3058 2021, Vol. 11, No. 1

Scholl, R. W. (1981). Differentiating organisational commitment from expectancy as a motivating force. Academy of Management Review, 6(4), 589-599. https://doi.org/10.5465/amr.1981.4285698

Sonnentag, S. (2011). Research on work engagement is well and alive. European Journal of $\begin{array}{llll}\text { Work } \quad \text { and } & \text { Organizational }\end{array}$ https://doi.org/10.1080/1359432X.2010.510639

Wachira, J. M. (2013). Relationship between employee engagement and commitment in Barclays bank of Kenya (Master's thesis, University of Nairobi). Retrieved from http://erepository.uonbi.ac.ke:8080/xmlui/handle/123456789/58865

Wiener, Y. (1982). Commitment in organisations: A normative view. Academy of Management Review, 7, 418-428. https://doi.org/10.5465/amr.1982.4285349

Wiener, Y., \& Gechman, A. S. (1977). Commitment: A behavioral approach to job involvement. Journal of Vocational Behavior 10(1), 47-52. https://doi.org/10.1016/0001-8791(77)90041-0

\section{Copyright Disclaimer}

Copyright for this article is retained by the author(s), with first publication rights granted to the journal.

This is an open-access article distributed under the terms and conditions of the Creative Commons Attribution license (http://creativecommons.org/licenses/by/4.0/). 